\title{
Characterization of energy carriers obtained from the pyrolysis of white ash, switchgrass and corn stover - Biochar, syngas and bio-oil
}

\author{
Tianju Chen ${ }^{\mathrm{a}, \mathrm{b}, \mathrm{c}}$, Ronghou Liu ${ }^{\mathrm{a}, \mathrm{b}, *}$, Norman R. Scott ${ }^{\mathrm{a}, * *}$ \\ a Department of Biological and Environmental Engineering, Cornell University, Riley-Robb Hall, Ithaca, NY 14853, USA \\ ${ }^{\mathrm{b}}$ Biomass Energy Engineering Research Centre, School of Agriculture and Biology, Shanghai Jiao Tong University, 800 Dongchuan Road, Shanghai 200240 , PR China \\ ${ }^{c}$ Key Laboratory of Biofuels, Qingdao Institute of Bioenergy and Bioprocess Technology, Chinese Academy of Sciences, 189 Songling Road, Qingdao 266101, PR China
}

\section{A R T I C L E I N F O}

\section{Article history:}

Received 7 July 2015

Received in revised form 30 September 2015

Accepted 30 September 2015

Available online $\mathrm{xxxx}$

\section{Keywords:}

Energy carrier

Pyrolysis

Biochar

Syngas

Bio-oil

\begin{abstract}
A B S T R A C T
The pyrolysis of three representative sources of biomass, namely, white ash, switchgrass and corn stover were investigated using a fixed-bed reactor to observe and compare the characterizations of three energy carriers, biochar, syngas and bio-oil. The characteristics of biochar were determined by Fourier Transform Infrared Spectroscopy (FT-IR), X-ray diffractometer (XRD) and Scanning Electron Microscopy Energy Dispersive Spectroscopy (SEM-EDS), Gas Chromatography (GC) and Gas Chromatography Mass Spectrometry (GC-MS).The results showed that the carbon content of biochar increased with the increase of pyrolysis temperature. More than $52 \mathrm{wt} . \%$ of the carbon was captured in the biochar. The infrared spectra of char samples illustrated that various bands in the spectra were identified, corresponding to stretches - $\mathrm{NH}-$, aliphatic stretches - $\mathrm{CH}-$, stretches conjugate $-\mathrm{C}=\mathrm{C}-,-\mathrm{CH}_{3}$ and stretches $-\mathrm{C}-\mathrm{O}-$. The surface morphology of biomass sample changed after pyrolysis and carbon fiber can be formed at the temperature of $500{ }^{\circ} \mathrm{C}$. The content of combustible gas $\mathrm{CH}_{4}, \mathrm{H}_{2}$ and $\mathrm{CO}$ was changed from $50 \%$ to $70 \%$. The GC-MS analysis of bio-oil showed that most of the chemical compounds detected were phenolic ones. This study provides a useful reference for energy carriers from the pyrolysis of biomass.
\end{abstract}

(C) 2015 Elsevier B.V. All rights reserved.

\section{Introduction}

The Earth's environment is threatened by an increase of $\mathrm{CO}_{2}$ in the atmosphere that can be attributed to the rapid consumption of fossil fuels during human development. Increasing anthropogenic $\mathrm{CO}_{2}$ emission and global warming have challenged the world to find new and better ways to meet the world's increasing needs for energy while reducing greenhouse gases [1]. Biomass was once an important source of energy for humankind and it is starting to play the role again [2] because biomass is a clean, cost-effective, $\mathrm{CO}_{2}$ neutral and low sulfur content renewable material which can be used for heat and fuel production [3].

Pyrolysis is a thermochemical conversion process, in which the feedstock is heated in the absence of air. Three kinds of energy carriers including biochar, bio-oil and syngas are produced from biomass pyrolysis process [4].There are two kinds of pyrolysis: fast pyrolysis and slow pyrolysis. The main production is bio-oil from the fast pyrolysis. Properties and chemical composition of bio-oil are distinct from petroleum fuel. In general terms, with its relatively high content of water

\footnotetext{
* Correspondence to: R. Liu, Department of Biological and Environmental Engineering, Cornell University, Riley-Robb Hall, Ithaca, NY 14853, USA.

** Corresponding author.

E-mail addresses: liurhou@sjtu.edu.cn (R. Liu),nrs5@cornell.edu (N.R. Scott).
}

and oxygen, bio-oil is acidic and not stable when heating, and its heating value lower than petroleum. Bio-oil is easy to transport, making biomass a dominant choice for the replacement of fossil fuels [5]. Its use as fuel in boilers and engines has been tested [6,7]. The content of the syngas is primarily $\mathrm{CO}, \mathrm{H}_{2}, \mathrm{CH}_{4}$ and $\mathrm{CO}_{2}$ which can be used as the heat source in a recycling fluidized-bed reactor [8]. Biochar is like charcoal and is the solid component created by pyrolysis of biomass. It is proposed as a source for carbon sequestration via carbon capture and storage. Thus, biochar has the potential to help mitigate climate change, via carbon sequestration. It can be used as a soil amendment, and has, also, attracted attention due to its ability for long term improvements of soil physical and chemical properties, with potentially important beneficial effects on soil biota [9]. Specifically, biochar may improve water infiltration, soil water retention, ion exchange capacity [10], $\mathrm{pH}[11,12]$, and improve $\mathrm{N}$ use efficiency. The substantial changes in bulk soil properties and biochar particles have shown to influence soil biological processes with significant implications for soil biogeochemistry [13]. Biochar can be used as an activated carbon when its pore structure and surface area are appropriate [14]. In addition, biochar can act as a soil conditioner enhancing plant growth, and more importantly, retain nutrients and provide other benefits such as improvement of soil physical and biological properties [15-21].

Furthermore, biochar is carbon-rich (typically more that $60 \%$ carbon) solid, which is mainly composed of aromatic hydrocarbons, simple 
substance carbon, or carbon with graphene structure [18]. It exhibits better biology stability and thermo-stability than precursor biomass. Also, biochar has a higher energy density and is therefore regarded as better fuel than the precursor raw biomass. It could be used as a solid fuel in boilers where bagasse or other biomass is presently burned [19-21]. Abdullah et al. [19] investigated the significant differences in the fuel quality and ash properties of biochars produced from the slow pyrolysis of various mallee biomass components (leaf, wood and bark) at five temperatures. The results show that biochars of all mallee biomass have better fuel qualities, such as lower moisture content, better grind ability, and higher energy density than the original biomass material [19]. Cao et al. [22] also reported that dairy manure can be efficiently converted into a biochar material with potential to serve as an amendment for remediation and agronomic purposes. The existing literature has primarily focused on the characterizations of biochar while syngas and bio-oil are useful energy carriers. The carrier gas was also used in previous studies, which can obviously decrease the content of combustible gases such as $\mathrm{CO}, \mathrm{H}_{2}$ and $\mathrm{CH}_{4}$. Up to date, the existing literature has only focused on the characterizations of biochar or bio-oil. With respect to studies of two or more energy carriers, Mahinpey et al. [23] examined the influence of pyrolysis pressure on product yield from wheat straw pyrolysis. Uzun et al. [21] studied the characteristic and quantities of bio-oil and biochar from the pyrolysis of tea waste. However, comprehensive investigations of three energy carriers are rather lacking. This research addresses the areas of comprehensive investigations of biooil, biochar and syngas obtained from slow pyrolysis of biomass.

In previous research, the kinetic analysis of biomass pyrolysis [24,25] and the characterizations of biochar, syngas and bio-oil were investigated [26,27]. The main objective of this research was to investigate the characteristics of biochar, syngas and bio-oil from slow pyrolysis of white ash wood, switchgrass and corn stover at the temperature range from $300^{\circ}{ }^{\circ} \mathrm{C}$ to $500^{\circ}{ }^{\circ} \mathrm{C}$. The slow pyrolysis of biomass was conducted in a fixed bed reactor. The characteristics of biochar, syngas and bio-oil can provide a useful reference for energy carriers from the pyrolysis of biomass.

\section{Methods}

\subsection{Materials}

In this experimental study, three kinds of biomass were used: white ash chips (a wood material, Telenet company, New York), switchgrass (a grass, from Cornell University farm) and corn stover (a crop waste material, from Cornell University farm). White ash samples were cut to about $1.5 \mathrm{~cm}^{2}$ in size, $3 \mathrm{~mm}$ thick and corn stover was cut to 5 $7 \mathrm{~cm}$ in length. Switchgrass remained untreated with an approximate length of $30 \mathrm{~cm}$. The proximate and ultimate analyses of the three types of feedstocks are listed in Table 1. Volatile matter and ash content were determined using a slightly modified ASTM method (D-1762-84) involving measurement of weight loss following combustion of about $10 \mathrm{~g}$ biomass in a ceramic crucible at $900^{\circ} \mathrm{C}$ for $7 \mathrm{~min}$ and $750^{\circ} \mathrm{C}$ for $6 \mathrm{~h}$, respectively. Fixed carbon was determined by mass balance following $C$ analysis of the nonvolatile residue. The feedstock was put into an oven to outgas the water content at the temperature of $105^{\circ} \mathrm{C}$ for $12 \mathrm{~h}$ before experiments.

\subsection{Experimental apparatus and procedure}

A fully controlled, slow pyrolysis reactor system was specifically designed and used for slow pyrolysis experiments. The schematic diagram of the system is shown in Fig. 1. It can be seen that the reactor system includes reaction section, condenser unit, filter, gas flow meter, gas collection and gas analysis. The reactor was made of stainless steel with a thermocouple and an auto temperature controller to control reaction temperature. The reactor (height $=490 \mathrm{~mm}$, inner diameter $=$ $310 \mathrm{~mm}$ ) is heated by an electric tubular furnace. About $1.0 \mathrm{~kg}$ of feedstock can be put into the reactor. In this work, the temperature was heated from room temperature to the set temperature $\left(300^{\circ} \mathrm{C}\right.$, $400^{\circ} \mathrm{C}$, or and $500^{\circ} \mathrm{C}$ ) with a heating rate of $10^{\circ}{ }^{\circ} \mathrm{C} \mathrm{min}^{-1}$, and held at set temperature for $120 \mathrm{~min}$. There was no carrier gas used in the pyrolysis process. With the increase of the temperature, the production of the hot vapors caused the pressure inside the reactor to increase. A soapywater solution was used to test the tightness of the reactor. Pyrolysis gases are condensed through a condenser system where cold water was used to condense the vapors to room temperature. Liquid production was collected in a liquid receiver. Corncob was used to filter the vapors. After the filter, the gas volume is measured by a wet gas flow meter (QW CROM, Lim. Co, Germany, QK 2000) and collected in a gas bag. Very little tar was condensed in the gas bag, so there was no special purification needed for the syngas in our experiment. Syngas of $50 \mathrm{~L}$ (sometimes $25 \mathrm{~L}$ ) was collected in each gas bag. The composition of the gas was determined by a gas chromatograph (GC).

\subsection{Analysis methods}

The thermal stability of the biomass was investigated by Thermogravimetric (TG) analysis. The characterizations of biochar including elemental analysis, ash content, the $\mathrm{pH}$ value and heating value were analyzed by Fourier Transform Infrared Spectroscopy (FT-IR), X-ray diffractometer (XRD) and Scanning Electron Microscopy Energy Dispersive Spectroscopy (SEM-EDS). The chemical composition of the liquid condensate was investigated by Gas Chromatography Mass Spectrometry (GC-MS).

\subsubsection{TG analysis}

The experiments were performed using a TG analyzer (TA Instruments, Q500, USA) at the temperature of $300^{\circ}{ }^{\circ} \mathrm{C}, 400^{\circ} \mathrm{C}$ and $500^{\circ} \mathrm{C}$, operating at the heating rate of $10^{\circ} \mathrm{C} \mathrm{min}^{-1}$. Samples were kept at the reaction temperature for $1 \mathrm{~h}$. A thin layer of the sample (ca. $10 \mathrm{mg}$ ) was distributed evenly in a ceramic crucible. During heating, mass and temperature of the sample were simultaneously and continuously recorded. In the pyrolysis experiments, $\mathrm{N}_{2}$ of ultra-high purity was passed through the TGA at a constant flow rate of $100 \mathrm{~mL} \mathrm{~min}^{-1}$ to provide the inert gas environment and to sweep away the volatiles released.

\subsubsection{Elemental analysis}

The elemental content of the pyrolysis oils and biochar was determined by a Model 240C Perkin-Elmer Elemental Analyzer. In the method, c Carbon, hydrogen and nitrogen were simultaneously determined as gaseous products (carbon dioxide, water vapor and nitrogen). The oxygen content was calculated by difference.

Table 1

The proximate and ultimate analyses of feedstocks.

\begin{tabular}{|c|c|c|c|c|c|c|c|}
\hline \multicolumn{4}{|l|}{ Proximate analysis } & \multicolumn{4}{|c|}{ Elemental analysis } \\
\hline & White ash & Switch-grass & Corn stover & & White ash & Switch-grass & $\overline{\text { Corn stover }}$ \\
\hline Moisture (wt.\%) & $10.54 \pm 0.07$ & $7.82 \pm 0.17$ & $9.18 \pm 0.14$ & C (wt.\%) & 47.45 & 47.50 & 49.58 \\
\hline Volatiles (wt.\%) & $75.83 \pm 0.68$ & $72.04 \pm 0.23$ & $74.76 \pm 0.46$ & $\mathrm{H}(\mathrm{wt} . \%)$ & 6.53 & 5.57 & 8.61 \\
\hline Fixed carbon (wt.\%) & $13.22 \pm 0.68$ & $15.46 \pm 0.23$ & $12.66 \pm 0.48$ & $\mathrm{~N}(\mathrm{wt} . \%)$ & 0.43 & 0.65 & 0.38 \\
\hline Ash (wt.\%) & $0.41 \pm 0.05$ & $4.68 \pm 0.03$ & $3.40 \pm 0.42$ & $\mathrm{O}^{\mathrm{a}}(\mathrm{wt} . \%)$ & 45.59 & 45.28 & 41.43 \\
\hline
\end{tabular}

a By difference. 


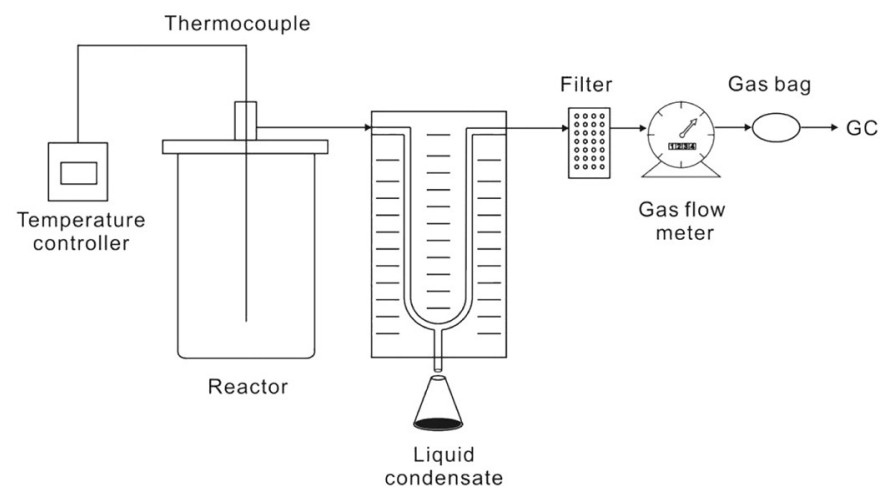

Fig. 1. The schematic diagram of the system.

\subsection{3. $\mathrm{pH}$ value}

The $\mathrm{pH}$ of biochar was determined in a mixture of $5 \mathrm{~g}$ biochar and $20 \mathrm{~mL}$ de-ionized water following $1 \mathrm{~h}$ equilibrium. The $\mathrm{pH}$ level was measured with a hand-held meter (Oakton pH 6, Vernon Hills, IL).

\subsubsection{Heating value}

The heating value of biochar was determined using an oxygen bomb calorimeter (Parr 6300, USA) according to ASTM D 5468-95. A thin layer of the biochar sample (ca. $1 \mathrm{~g}$ ) was distributed evenly in the oxygen

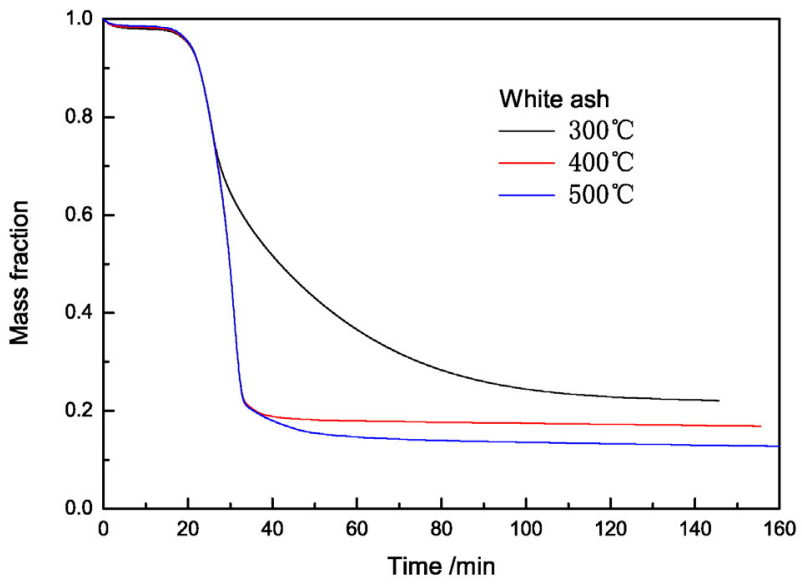

(a) bomb calorimeter. The pressure of the oxygen was kept at 450 Psi for 1 min.

\subsubsection{FT-IR}

The biochar was mixed with $\mathrm{KBr}$ powder which had been dried at $105^{\circ} \mathrm{C}$ at a ratio of $3 \mathrm{mg}$ biochar: $1000 \mathrm{mg} \mathrm{KBr}$ for all biochar samples. The biochar-powder mixture was then re-ground in a mortar and pestle to ensure homogeneity and was stored in a desiccator. Pellets were created using $150-250 \mathrm{mg}$ of powder in a pellet press at $10 \mathrm{MPa}$ of pressure. Two pellets were created for each biochar. Using a Mattson Model 5020 FT-IR Spectrometer (Madison, WI) at wave numbers from 400 to $4000 \mathrm{~cm}^{-1}$, each sample was scanned 100 times, with a resolution of $4 \mathrm{~cm}^{-1}$, subtracting a blank value obtained from a pure $\mathrm{KBr}$ pellet.

\subsection{6. $X R D$}

XRD analysis was carried out to identify crystallographic structure in the biochar samples using a computer-controlled X-ray diffractometer (Bruker: D8 Advance, Germany) equipped with a stepping motor and graphite crystal monochromator.

\subsubsection{SEM-EDS}

The morphology of the white ash particles and white ash biochars was characterized using SEM-EDS. The samples were coated with gold to achieve good visibility of the images. Images were taken at $15 \mathrm{kV}$ with a JSM-6360 model SEM-EDS.

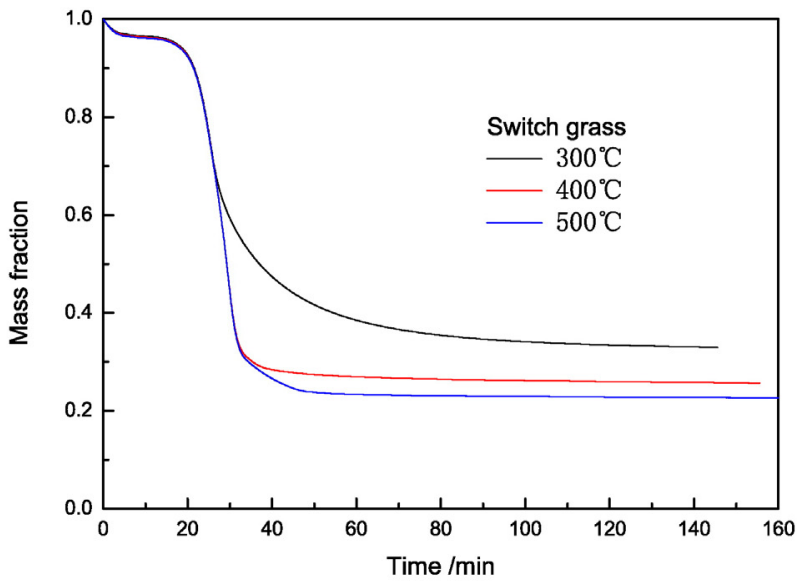

(b)

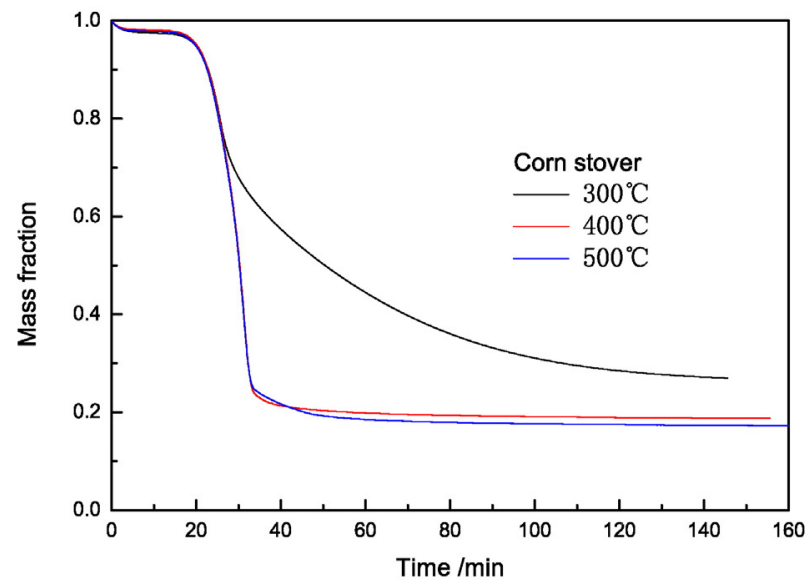

(c)

Fig. 2. Thermogravimetric analyses for the feedstocks under different temperatures: (a) white ash, (b) switch grass, (c) corn stover. 
Table 2

The effect of the temperature on the product yields and the characteristics of biochar from the biomass pyrolysis.

\begin{tabular}{|c|c|c|c|c|c|c|c|c|c|c|c|c|}
\hline Biomass & Temperature $/{ }^{\circ} \mathrm{C}$ & $\begin{array}{l}\text { Biochar } \\
\text { yield/wt.\% }\end{array}$ & $\begin{array}{l}\text { Bio-oil } \\
\text { yield/wt.\% }\end{array}$ & $\begin{array}{l}\text { Gas } \\
\text { volume/L }\end{array}$ & $\mathrm{C}$ & $\mathrm{H}$ & $\mathrm{N}$ & $\mathrm{O}^{\mathrm{b}}$ & $\begin{array}{l}\text { Biochar carbon } \\
\text { yield/wt.\%a }\end{array}$ & ash & $\mathrm{pH}$ value & $\begin{array}{l}\text { Heating } \\
\text { value/MJ/kg }\end{array}$ \\
\hline \multirow[t]{3}{*}{ White ash } & 300 & 39.20 & 43.33 & 153.7 & 77.82 & 3.42 & 0.54 & 15.58 & 64.29 & 2.64 & $7.16 \pm 0.05$ & 30.9 \\
\hline & 400 & 31.04 & 40.65 & 179.7 & 87.6 & 2.50 & 0.56 & 6.27 & 57.30 & 3.07 & $7.23 \pm 0.12$ & 32.4 \\
\hline & 500 & 27.68 & 38.05 & 225.2 & 90.19 & 1.50 & 0.49 & 4.05 & 52.61 & 3.77 & $7.91 \pm 0.10$ & 33.5 \\
\hline \multirow[t]{3}{*}{ Switch grass } & 300 & 39.58 & 31.6 & 175.5 & 76.06 & 3.87 & 0.66 & 10.74 & 63.38 & 8.67 & $8.22 \pm 0.10$ & 28.9 \\
\hline & 400 & 36.72 & 28.5 & 205.0 & 80.77 & 3.02 & 0.64 & 5.27 & 62.44 & 10.3 & $8.42 \pm 0.06$ & 30.2 \\
\hline & 500 & 29.34 & 27.5 & 271.3 & 86.33 & 1.90 & 0.59 & 0.54 & 53.32 & 10.64 & $8.6 \pm 0.10$ & 31.5 \\
\hline \multirow[t]{3}{*}{ Corn stover } & 300 & 41.72 & 31.03 & 175.5 & 69.91 & 4.04 & 0.94 & 13.42 & 58.83 & 11.69 & $7.31 \pm 0.01$ & 28 \\
\hline & 400 & 35.44 & 30.7 & 213.0 & 74.78 & 3.15 & 1.05 & 6.18 & 53.45 & 14.84 & $7.79 \pm 0.11$ & 28.8 \\
\hline & 500 & 33.50 & 26.73 & 239.7 & 78.11 & 2.11 & 0.92 & 3.77 & 52.78 & 15.09 & $8.1 \pm 0.15$ & 30.5 \\
\hline
\end{tabular}

a The $\mathrm{C}$ weight of the biochar from $1 \mathrm{~kg}$ biomass was equal to the product of the biochar yield and its $\mathrm{C}$ content. The ratio of the $\mathrm{C}$ weight of each biochar for the $\mathrm{C}$ content of $1 \mathrm{~kg}$ feedstock is equal to biochar carbon yield.

b By difference.

\subsubsection{Gas analysis}

Gas analysis was carried out using a Gas Chromatograph (GOWMAC Instrument Company, Series 580) equipped with thermal conductivity detector (TCD). Standard gases were used for calibration, and argon was used as the carrier gas. The ultra-high purity gases were used as the standard gases.

\subsubsection{GC-MS analysis}

Although bio-oil cannot be completely analyzed by GC-MS only, because it contains some large molecules as well as some undistillable matter that cannot be investigated by this technique only, it is still



(a) widely used to identify most compounds of bio-oils from the pyrolysis of biomass. The GC-MS system consists of a gas chromatograph coupled to a quadrupole mass spectrometer (GC-MS QP 2010, Shimadzu) using a capillary column $(30 \mathrm{~m} \times 0.25 \mathrm{~mm}$ i.d.; film thickness, $0.25 \mu \mathrm{m})$. Electron ionization (EI) was used with an ion source temperature of $230^{\circ} \mathrm{C}$ and interface temperature of $280^{\circ} \mathrm{C}$, with EI spectra obtained at $70 \mathrm{eV}$. In EI, the instrument was used in SCAN mode initially to confirm the identity of the compounds and then in SIM (selected ion monitoring) mode for quantitative analysis. The GC system was equipped with a split/splitless inlet. The injector temperature was $250^{\circ} \mathrm{C}$. A LEAP Technologies autosampler with a $10 \mu \mathrm{L}$ syringe was used for injections of

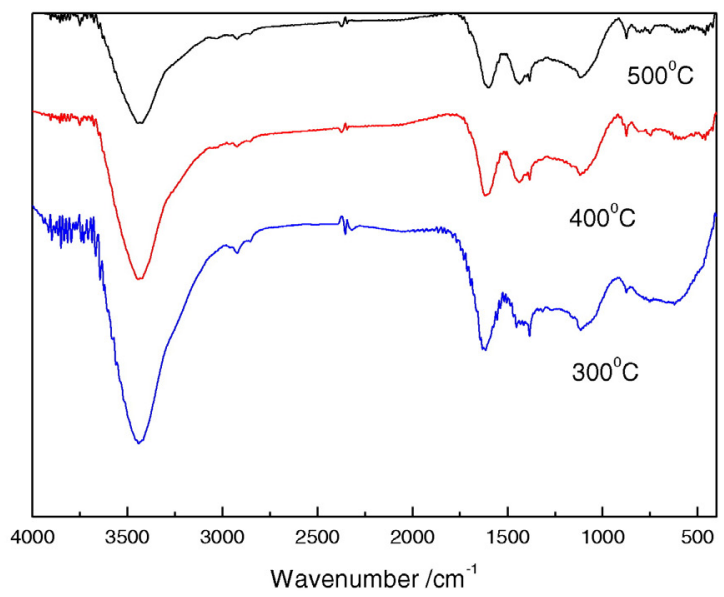

(b)

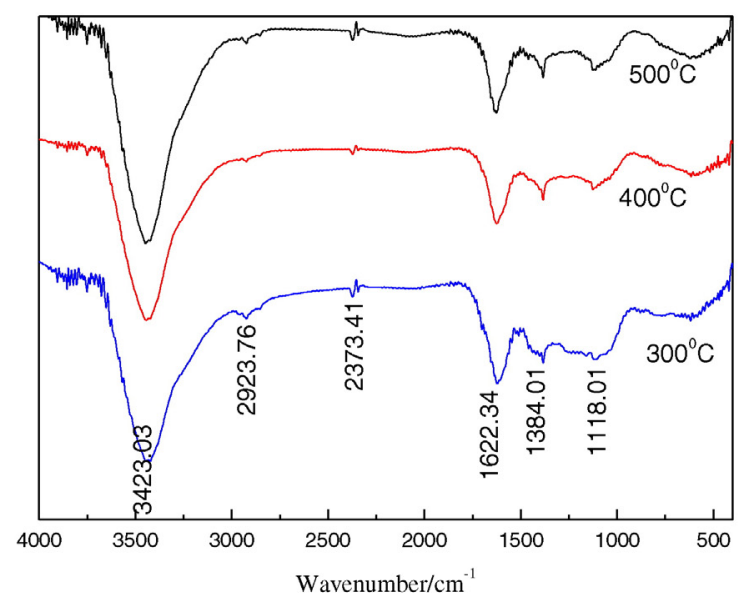

(c)

Fig. 3. FT-IR spectra of bio-char: (a) white ash, (b) switch grass, (c) corn stover. 


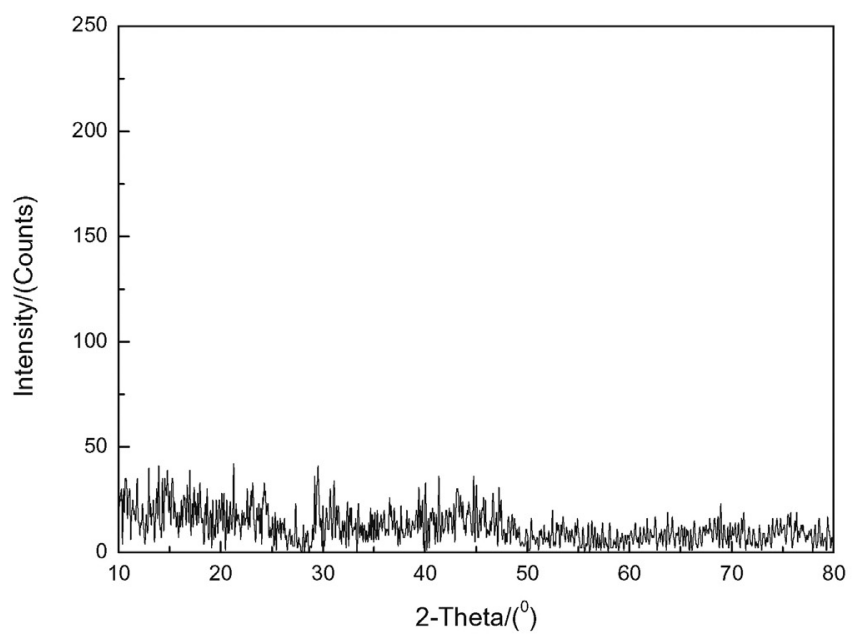

(a)

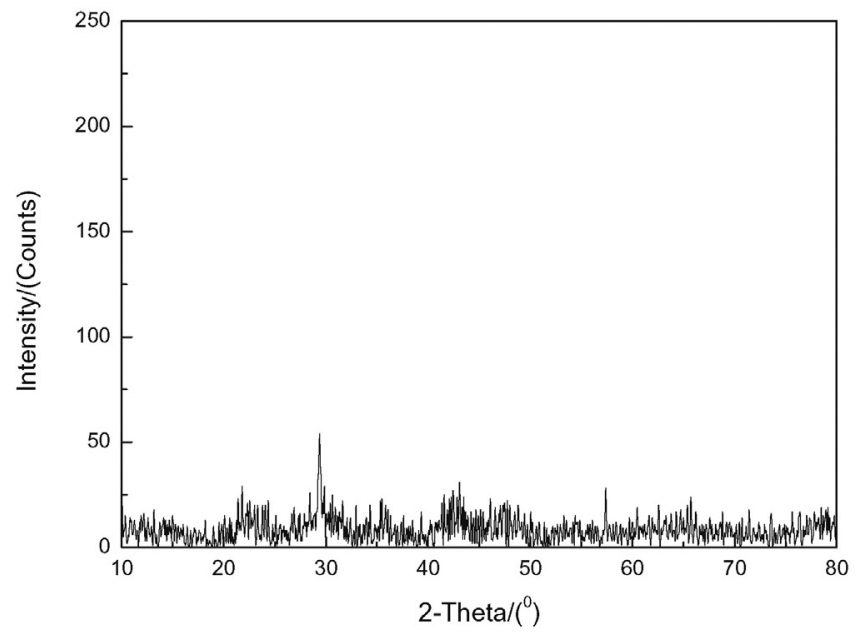

(c)

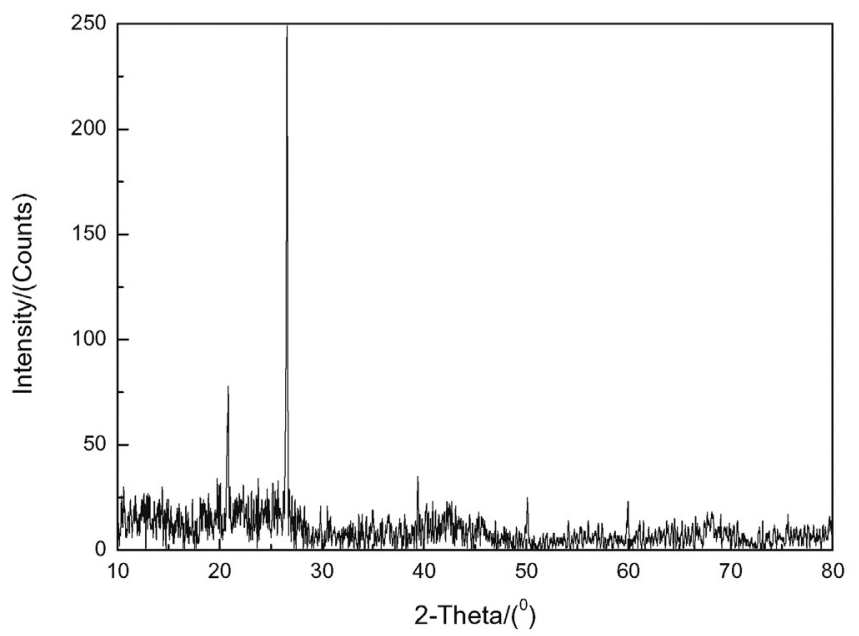

(e)

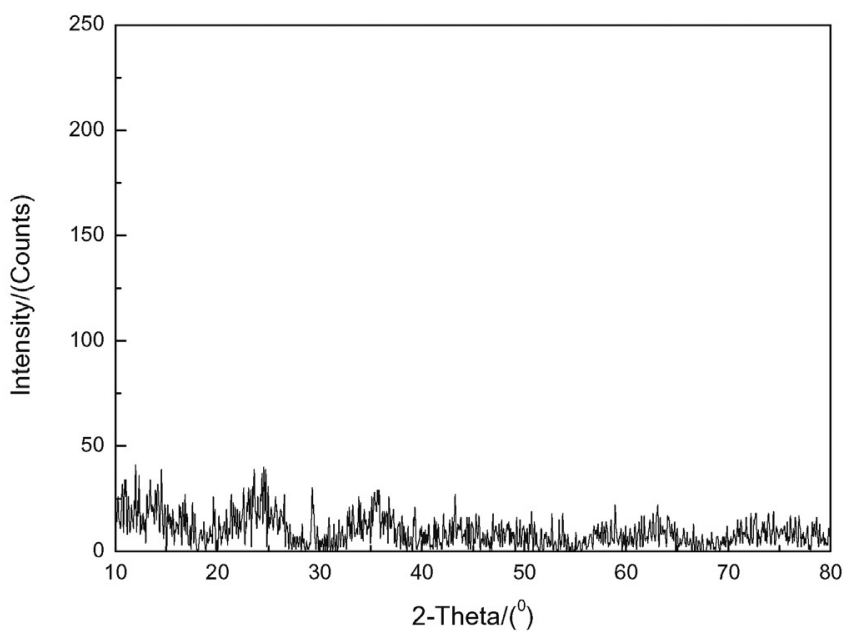

(b)

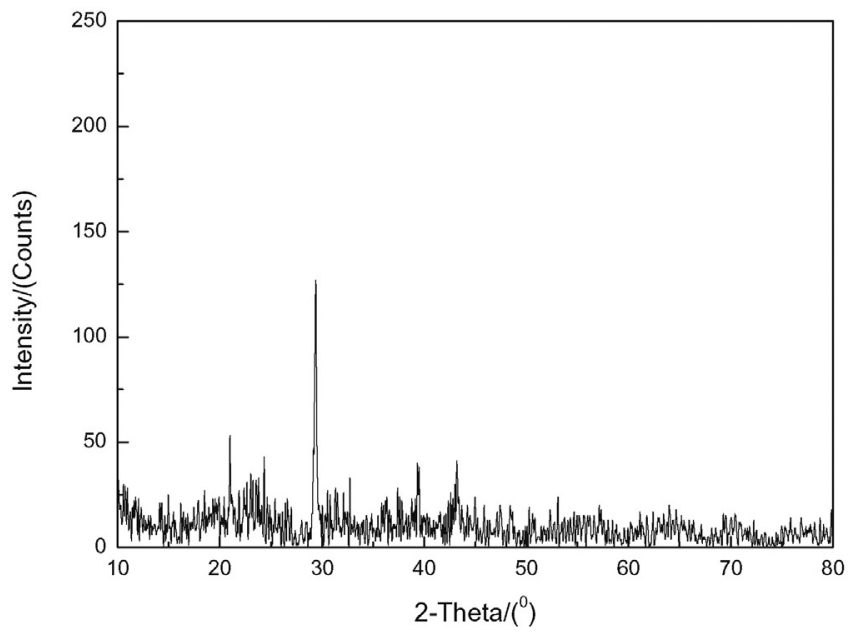

(d)

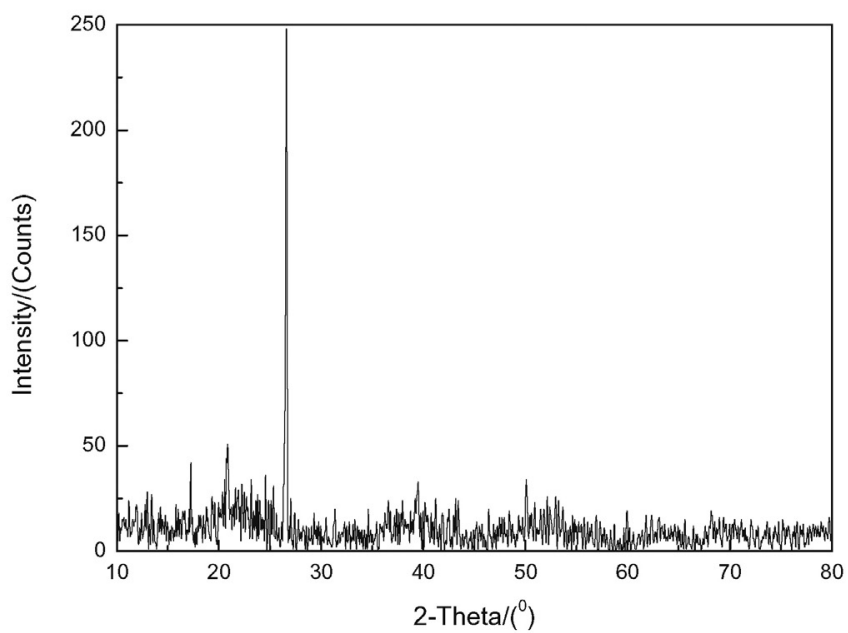

(f)

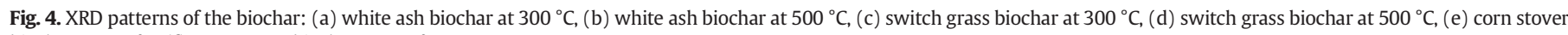
biochar at $300{ }^{\circ} \mathrm{C}$, (f) corn stover biochar at $500{ }^{\circ} \mathrm{C}$.

$1 \mu \mathrm{L}$ at a rate of $10 \mu \mathrm{L} \mathrm{s}^{-1}$. The carrier gas was helium (UHP) at a constant flow of $1.0 \mathrm{~mL} \mathrm{~min}^{-1}$. The oven temperature program had an initial temperature of $60^{\circ} \mathrm{C}$ held for $2.0 \mathrm{~min}$, rising by $8^{\circ}{ }^{\circ} \mathrm{C} \mathrm{min}^{-1}$ to $300^{\circ} \mathrm{C}$, which was held for $10.0 \mathrm{~min}$ with a total run time of $35.0 \mathrm{~min}$. This temperature program was selected to provide adequate separation of most of the compounds of interest. 


\section{Results and discussion}

\subsection{Pyrolysis behavior and its mass balance}

\subsubsection{TG analysis of biomass}

In Fig. 2(a), it can be seen that the weight loss of white ash increased with the increase of pyrolysis temperature. The weight loss continued to decrease when the temperature reached $300^{\circ} \mathrm{C}$. However, at temperatures of $400^{\circ} \mathrm{C}$ and $500^{\circ} \mathrm{C}$, the weight loss is small. In Fig. 2(b and c), it can be seen that switchgrass and corn stover had the same trend as white ash because the biomass material was typically composed of cellulose, hemicellulose and lignin. Basak et al. [21] reported that hemicellulose began to thermally decompose at $150^{\circ}{ }^{\circ} \mathrm{C}-350^{\circ}{ }^{\circ} \mathrm{C}$, and cellulose degradation appeared between $275^{\circ}{ }^{\circ} \mathrm{C}$ and $350^{\circ}{ }^{\circ} \mathrm{C}$. However, lignin degradation took place at $200^{\circ} \mathrm{C}-700^{\circ} \mathrm{C}$. For these results, temperatures were raised to the selected temperature at a heating rate of $10^{\circ}{ }^{\circ} \mathrm{C} \mathrm{min}{ }^{-1}$ and held for $1 \mathrm{~h}$. After $1 \mathrm{~h}$ of heating, the furnace was turned off and the sample was cooled to room temperature.

\subsubsection{Mass balance of biomass pyrolysis}

Biochar, bio-oil and syngas are produced from slow pyrolysis of biomass. The biochar is a black solid material. The bio-oil is a dark brown
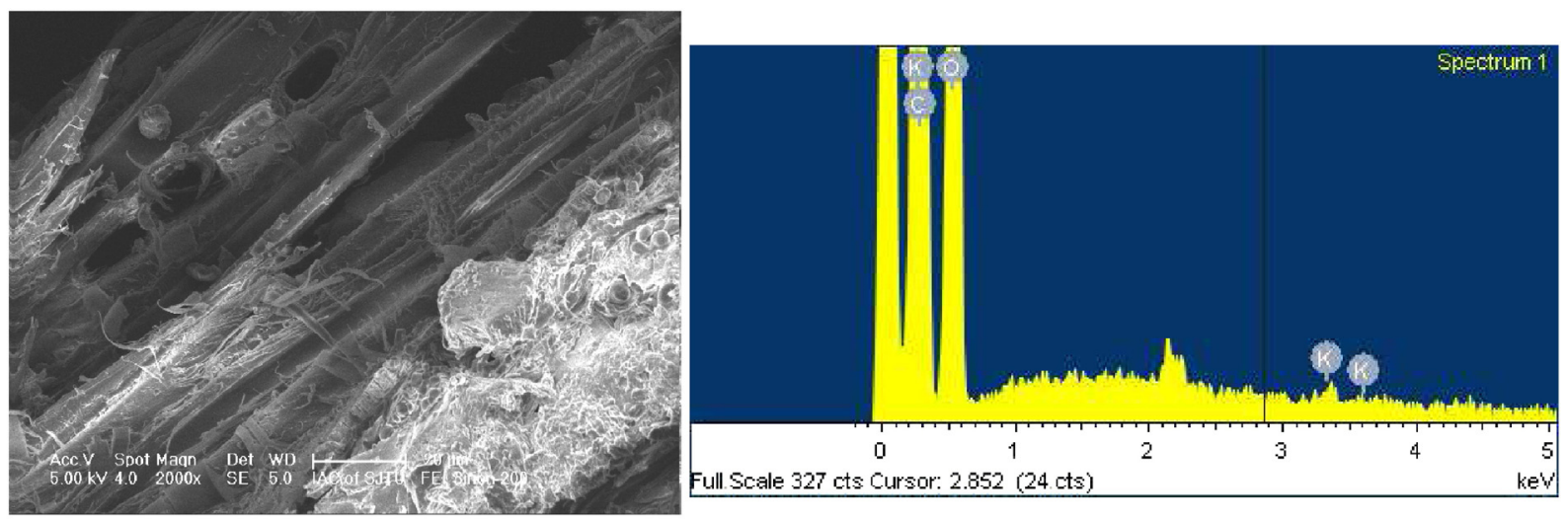

(a)
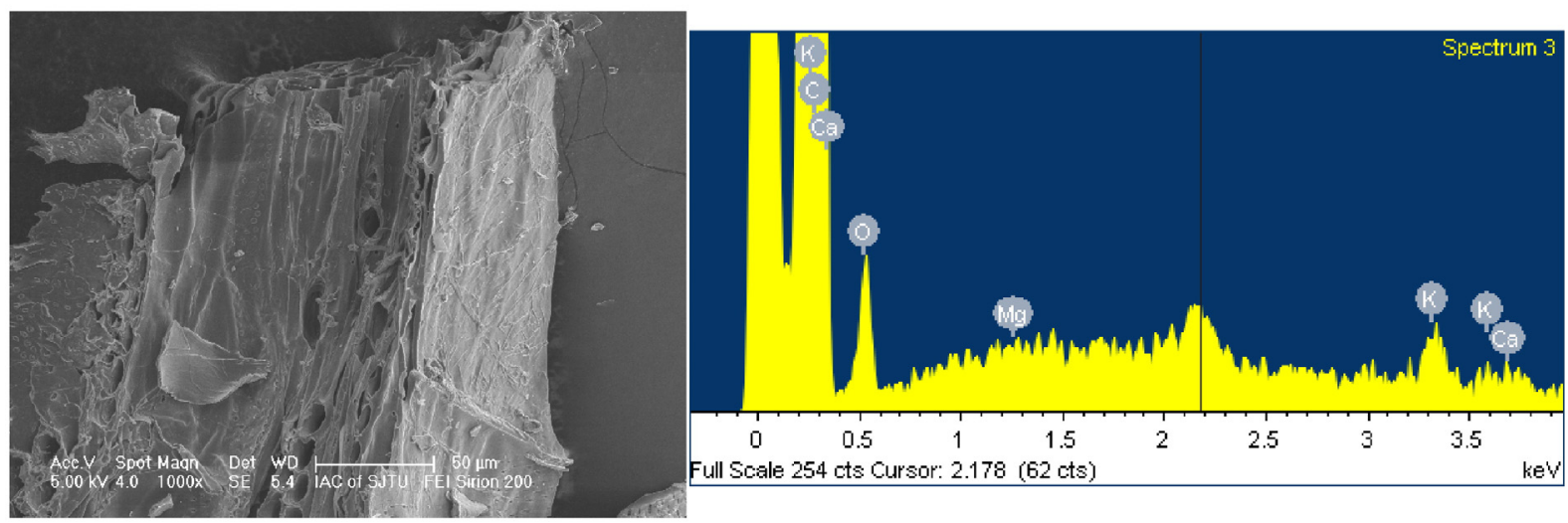

(b)


(c)

Fig. 5. SEM-EDS analysis: (a) white ash, (b) biochar at $300{ }^{\circ} \mathrm{C}$, (c) biochar at $400{ }^{\circ} \mathrm{C}$, (d) biochar at $500{ }^{\circ} \mathrm{C}$, (e) carbon fiber from biochar at $500{ }^{\circ} \mathrm{C}$. 


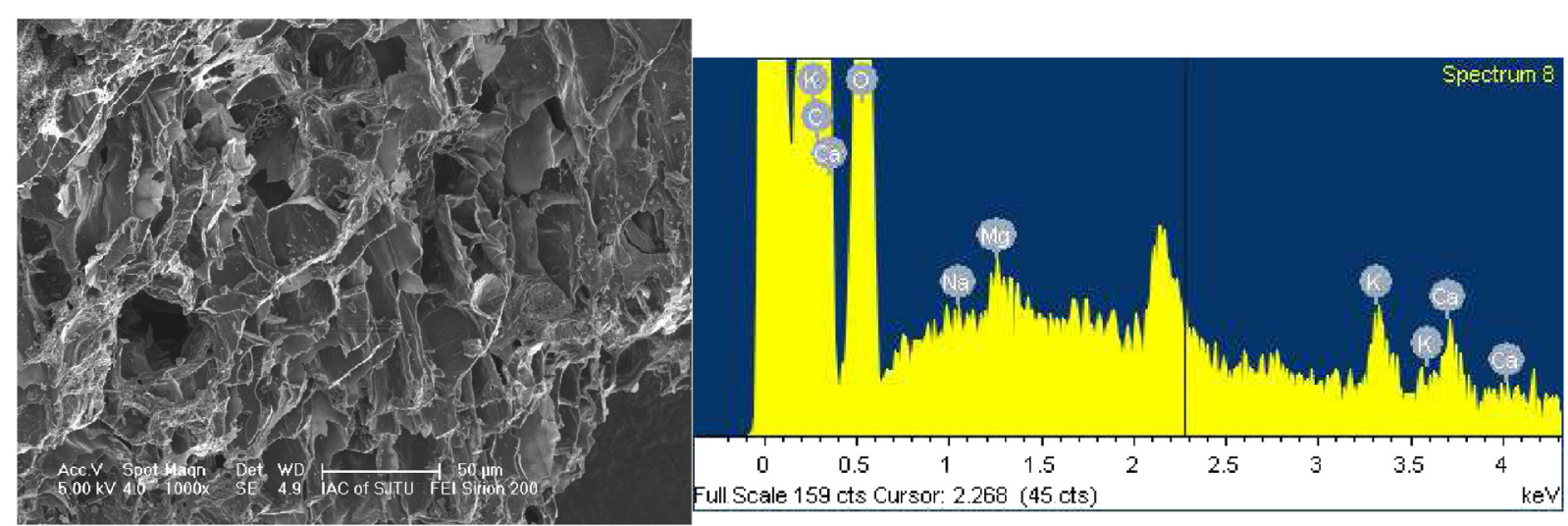

(d)

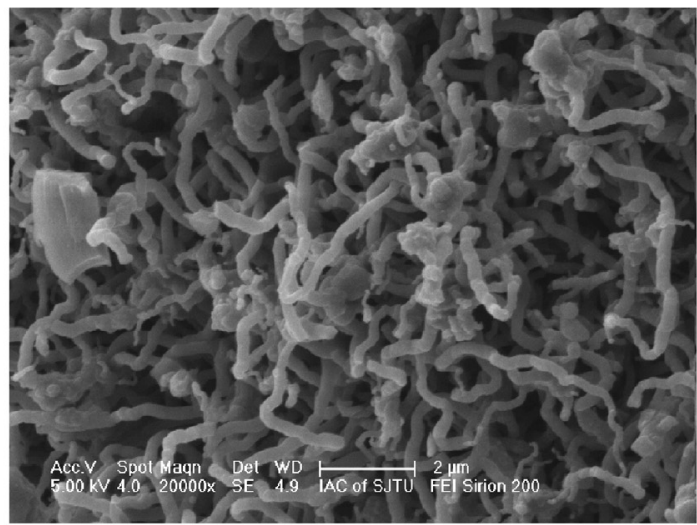

(e)

Fig. 5 (continued).

liquid which can be combusted. There are large quantities of $\mathrm{CO}, \mathrm{CH}_{4}$ and $\mathrm{H}_{2}$ (the combustible gas contents can be $60 \%$ ) in the syngas. The effect of temperature on the product yield from the biomass pyrolysis is shown in Table 2. In Table 2, it can be seen that for the three kinds of biomass, the biochar and bio-oil yields decreased with the increase of pyrolysis temperature. However, more syngas was produced at higher temperatures (the combustible gas contents were about $40-60 \%$ ). Corn stover had the highest biochar yield of $41.72 \%$ at $300^{\circ} \mathrm{C}$ and a lower yield of $33.50 \%$ at $500^{\circ}{ }^{\circ} \mathrm{C}$, while white ash had the lowest yield of $39.20 \%$ at $300^{\circ} \mathrm{C}$, compared to $27.68 \%$ at $500^{\circ} \mathrm{C}$. Biochar derived from corn stover had a higher ash content (about $10 \mathrm{wt} . \%)$, with increased pyrolysis temperature.

\subsection{Characteristic of biochar}

\subsubsection{Elemental analysis}

The effect of temperature on the elemental analyses and the ash content of biochar is shown in Table 2. In Table 2, it can be seen that for all three biochars, the hydrogen and oxygen content decreased with the increase of pyrolysis temperature, and carbon and ash content increased with the increase of temperature. The carbon content of the biochar from the white ash was higher than that from the switch grass and corn stover. The carbon content was $90.2 \%$ for the biochar from white ash at the temperature of $500^{\circ} \mathrm{C}$. Because biochar has a stable structure, it has the potential to help mitigate climate change, via carbon sequestration. Table 2 also showed that carbon sequestration rates decreased with the increase of the temperature, and more than $52 \%$ of the carbon was captured in biochar. Secondary decomposition of the biochar took place at higher temperature, and more $\mathrm{CO}, \mathrm{CH}_{4}, \mathrm{CO}_{2}$ and chemical compounds containing carbon were produced. That is why the carbon sequestration rate decreased at high temperature.

\subsection{2. $\mathrm{pH}$ value}

In Table 2, it can be seen that the biochar is alkaline. The $\mathrm{pH}$ value increased with the increase of pyrolysis temperature. The switch grass biochar has a higher $\mathrm{pH}$ value than the corn stover and white ash, with a pH value of 8.5 at $500^{\circ} \mathrm{C}$. These results indicate that biochar has potential as an amendment to neutralize soil acidity [22]. The alkali metals of $\mathrm{Na}, \mathrm{K}, \mathrm{Ca}$ and $\mathrm{Mg}$ were detected in biochar in our previous study [26]. Although more volatiles were released with the increase of pyrolysis temperature, the alkali metals were difficult to volatile in the biomass pyrolysis process. Therefore, the contents of alkali metals in the biochar increased with the increasing pyrolysis temperature. The switchgrass had the highest ash content. The content of alkali metals in the biochar from switchgrass was higher than from white ash and corn stover and is why the switchgrass biochar had the highest $\mathrm{pH}$ value.

\subsubsection{Heating value}

It can be seen in Table 2 that the heating value increased with the increase of the reaction temperature. The heating value is determined by the carbon content and white ash biochar has the highest carbon content. Thus, it has a higher heating value than switch grass and corn stover biochar with a heating value of $33.0 \mathrm{MJ} \mathrm{kg}^{-1}$ at $500^{\circ} \mathrm{C}$. It has been reported that converting biomass to biochar would lead to a substantial increase in fuel mass energy density from $\sim 10 \mathrm{MJ} \mathrm{kg}^{-1}$ of green biomass to $\sim 28 \mathrm{MJ} \mathrm{kg}^{-1}$ for biochar $[19,20]$. 


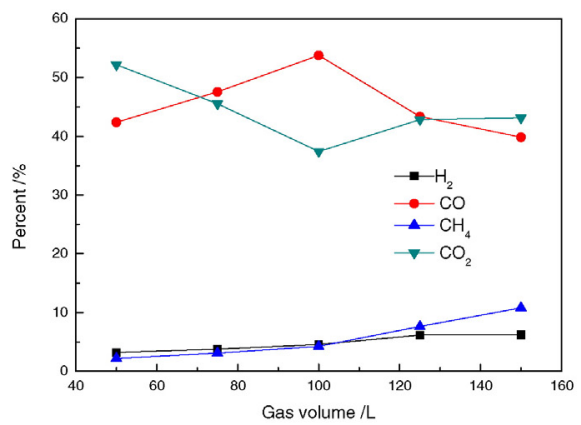

(a)

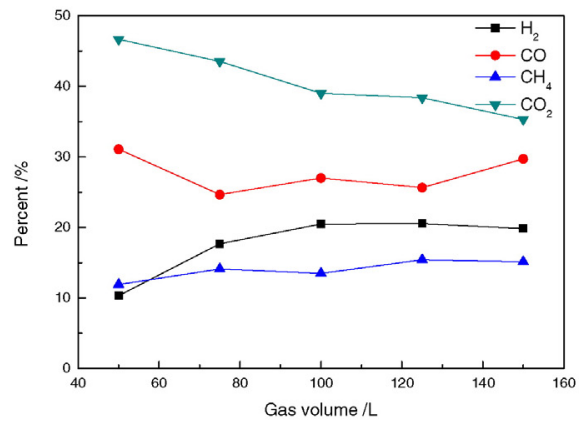

(d)

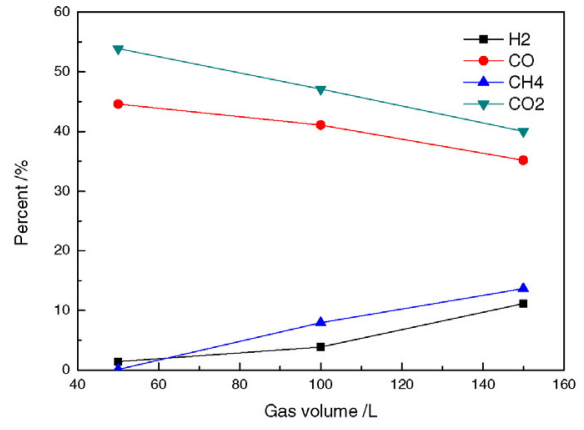

(g)

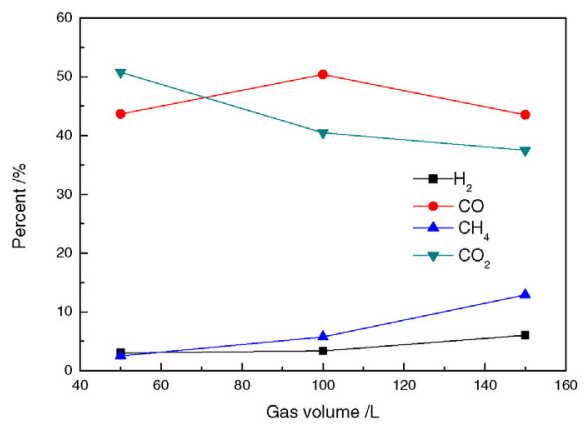

(b)

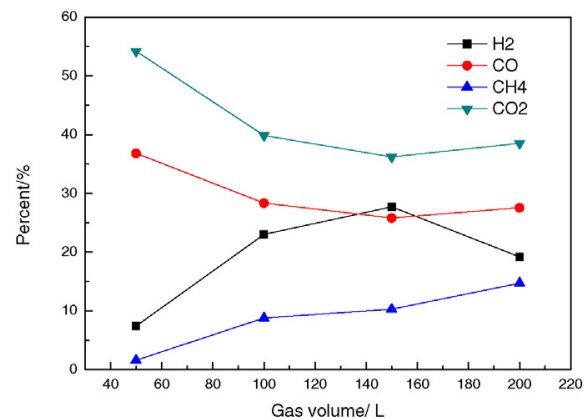

(e)

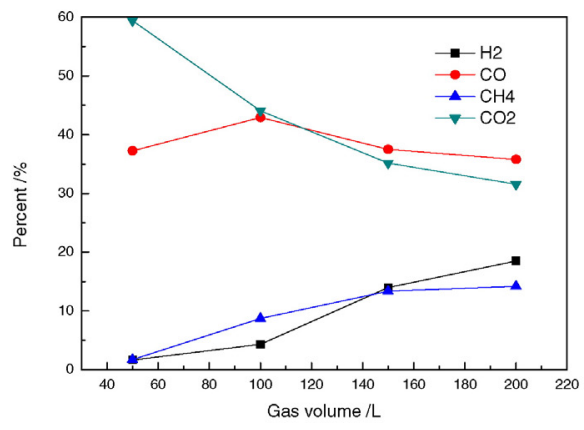

(h)

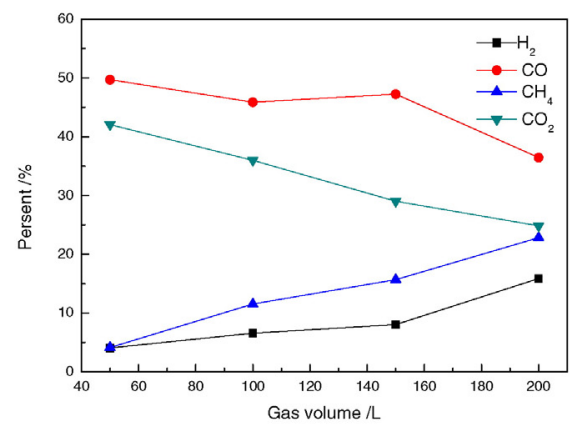

(c)

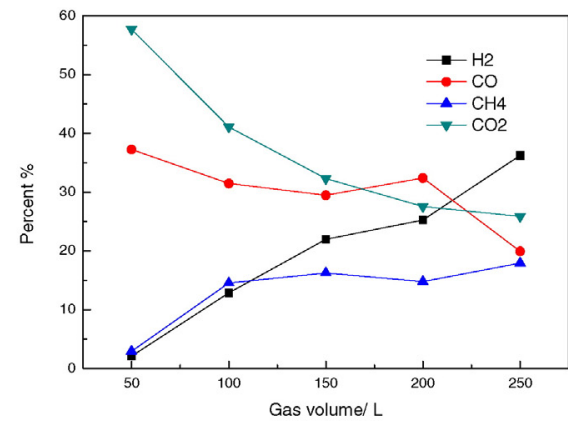

(f)

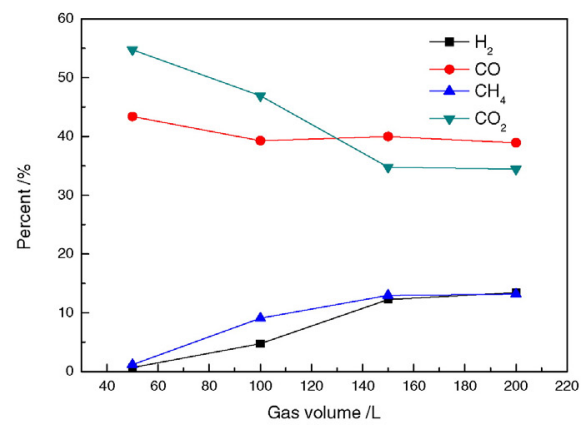

(i)

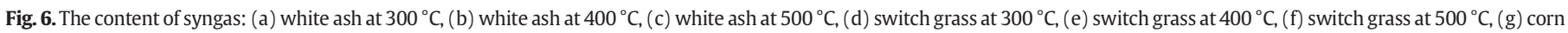
stover at $300{ }^{\circ} \mathrm{C},(\mathrm{h})$ corn stover at $400{ }^{\circ} \mathrm{C}$, (i) corn stover at $500{ }^{\circ} \mathrm{C}$.

\subsubsection{FT-IR}

In the pyrolysis process, the biomass feedstocks cannot be pyrolyzed completely. The results of elemental analysis of the biochar showed that there is a large amount of carbon, hydrogen and oxygen in the biochar. Thus, there must be a lot of chemical bonds in biochar. Fouriertransform infrared (FT-IR) spectroscopy represents an advanced version of the more traditional infrared (IR) spectroscopy method. FT-IR is primarily used for the structural determination of organic (carbonbased) molecules. FT-IR has also been used to describe characteristic bonds of biochar [28]. FT-IR spectra of biochar: (a) white ash, (b) switch grass and (c) corn stover are shown in Fig. 3. In Fig. 3 it can be seen that the infrared spectra of biochar samples illustrates various bands in the spectra, corresponding to stretches $\mathrm{N}-\mathrm{H}\left(3423 \mathrm{~cm}^{-1}\right)$, aliphatic stretches $\mathrm{C}-\mathrm{H}\left(2923 \mathrm{~cm}^{-1}\right)$, stretches conjugate $\mathrm{C}=\mathrm{C}$ $\left(1622 \mathrm{~cm}^{-1}\right),-\mathrm{CH}_{3}\left(1384 \mathrm{~cm}^{-1}\right)$ and stretches $\mathrm{C}-\mathrm{O}\left(1118 \mathrm{~cm}^{-1}\right)$ [27]. The broad bands at $3423 \mathrm{~cm}^{-1}$ were attributed to the hydroxyl groups $(\mathrm{O}-\mathrm{H})$ due to the water content in the nine biochars. The presence of water in the biochars could be from absorption of moisture by the biochars or $\mathrm{KBr}$ during pellets preparation [29]. For the nine biochars, all of them have the same chemical bonds. That is because the biomass material consists of cellulose, hemicellulose and lignin which have a large amount of $\mathrm{C}, \mathrm{H}$ and $\mathrm{O}$ [24]. It can also be seen that the strength of all chemical bonds was enhanced with the decrease of the temperature, which was also confirmed by Lee et al. [28]. Secondary decomposition of the biochar took place at higher temperatures, which led to the strength of all chemical bonds being weaker. All the bands in the bio-char can be found except the $\mathrm{C}-\mathrm{C}$ bond. In general, ether- and ester-linkages can be cleaved via pyrolysis. The $\mathrm{C}-\mathrm{C}$ bond has the longest bond length $\left(154 \times 10^{-12} \mathrm{~m}\right)$ and has the lowest bond energy $\left(332 \mathrm{kJmol}^{-1}\right)$. This kind of chemical bonds is easier to cleave at high temperature [27].

\subsubsection{XRD analysis}

In order to know the crystalline compounds in the biochar samples, XRD detection was used and the results are shown in Fig. 4. It can be seen that all the biochar samples had a strong peak at $28^{\circ}$ that was identified as $C\left(C_{12}\right.$ and $\left.C_{60}\right)$, which was in agreement with Wu et al. [30] that there existed crystalline $\mathrm{C}$ in different biochar samples. The XRD spectra is stronger at $500^{\circ} \mathrm{C}$ than at $300^{\circ} \mathrm{C}$. That is because carbon content of the biochar is very high at higher temperature. More crystalline $\mathrm{C}$ 
Table 3

The effect of temperature on components of bio-oil from white ash wood pyrolysis and their relative mass contents detected by GC-MS.

\begin{tabular}{|c|c|c|c|c|c|c|c|}
\hline \multirow{2}{*}{ Peak number } & \multirow{2}{*}{ Main identified compounds } & \multirow{2}{*}{$\mathrm{RTA}(\min )$} & \multirow{2}{*}{ Mol. mass } & \multirow{2}{*}{ Qualitative ion, mass-to charge ratio $(\mathrm{m} / \mathrm{z})$} & \multicolumn{3}{|c|}{ Temperature $\left({ }^{\circ} \mathrm{C}\right)$} \\
\hline & & & & & 300 & 400 & 500 \\
\hline 1 & Pyruvic acid & 2.2 & 88 & $18,58,59$ & & & 0.73 \\
\hline 2 & Oxiranemethanol, acetate & 2.7 & 116 & $18,42,73$ & 10.57 & & 12.11 \\
\hline 3 & 1-Hydroxy-2-pentanone & 3.37 & 102 & $18,32,58$ & 0.55 & & 0.81 \\
\hline 4 & Furfural & 3.55 & 96 & $18,43,71$ & 10.15 & 14.97 & 12.35 \\
\hline 5 & Furfuryl alcohol & 3.85 & 98 & $18,43,58$ & & 11.11 & 7.17 \\
\hline 6 & N-propyl-acetamide & 4.31 & 101 & $18,28,32$ & 0.90 & & 0.68 \\
\hline 7 & 4-Amino-furazan-3-ol & 4.55 & 101 & $18,28,32$ & & & 1.46 \\
\hline 8 & Butyrolactone & 4.79 & 86 & $18,44,86$ & 8.15 & 8.10 & 6.58 \\
\hline 9 & 5-Methyl-2(5H)-furanone & 5.21 & 98 & $18,28,44$ & 0.49 & & 3.35 \\
\hline 10 & Phenol & 6.07 & 94 & $18,28,44$ & 2.96 & 4.60 & 4.14 \\
\hline 11 & Propanoic acid, 2-methyl-,anhydride & 6.52 & 158 & $18,69,102$ & 2.25 & & \\
\hline 12 & Corylon & 6.93 & 112 & $18,28,44$ & 4.34 & 4.78 & 3.56 \\
\hline 13 & 2-Methyl-phenol & 7.45 & 108 & $18,28,85$ & 2.85 & & \\
\hline 14 & 4-Methyl-phenol & 7.84 & 108 & $28,43,108$ & 3.90 & & \\
\hline 15 & 2-Methoxy-phenol & 8.15 & 124 & $18,44,57$ & 4.90 & 5.56 & 3.52 \\
\hline 16 & 3-Elthyl-2-hydroxy-2-cyclopenten-1-one & 8.69 & 126 & $28,38,97$ & 0.90 & & \\
\hline 17 & 2,5-Dimethyl-phenol & 9.23 & 122 & $18,44,57$ & 2.01 & 1.88 & \\
\hline 18 & 2,3-Dimethyl-phenol & 9.6 & 122 & $18,28,44$ & 0.83 & & \\
\hline 19 & 4-Methoxy-3-methyl-phenol & 9.82 & 138 & $18,28,44$ & 1.33 & & \\
\hline 20 & Metacetamol & 10.17 & 151 & $18,44,64$ & 8.36 & 11.70 & 8.11 \\
\hline 21 & 4-Methoxy-1,2-benzenediol & 11.3 & 140 & $18,44,124$ & 2.87 & 7.11 & 7.92 \\
\hline 22 & 4-Ehtyl-2-methoxy-phenol & 11.62 & 152 & $18,44,97$ & 4.66 & & \\
\hline 23 & 3,4-Dimethoxy-phenol & 12.84 & 154 & $18,44,107$ & 9.13 & 8.65 & 5.97 \\
\hline 24 & 2,5-Dimethyl-1,4-benzenediol & 13.38 & 138 & $18,44,58$ & 0.63 & 0.90 & \\
\hline 25 & 4-Methoxy-3-[methoxymethyl]phenol & 14.4 & 168 & $18,44,58$ & 4.70 & 3.69 & 3.32 \\
\hline 26 & D-allose & 14.94 & 180 & $29,73,98$ & 5.68 & 11.46 & 10.19 \\
\hline 27 & 1-Methyl-2-[2,3,5-trimethoxyphenyl]ethylamine & 15.66 & 225 & $18,28,44$ & 3.89 & 3.44 & 4.88 \\
\hline 28 & 3,4,5-Trimethoxy-N-methyl-benzenthanamine & 17.51 & 225 & $18,28,32$ & 0.88 & & \\
\hline 29 & 4-Allyl-2,6-dimethoxy-phenol & 18.2 & 194 & $18,44,105$ & 0.95 & & \\
\hline 30 & 1-[2,4,6-Trihydroxyphenyl],2-pentanone & 19.14 & 210 & $18,44,78$ & 1.17 & 2.06 & 3.17 \\
\hline
\end{tabular}

was formed at $500^{\circ} \mathrm{C}$. The XRD spectra of the biochar showed several peaks, including the peak at $21^{\circ}, 40^{\circ}$ and $51^{\circ}$. These results indicated that there were some mineral crystals such as $\mathrm{MgO}$ and $\mathrm{CaCO}_{3}$ in the biochar [22]. The existence of alkali metals ( $\mathrm{Na}, \mathrm{K}, \mathrm{Ca}$ and $\mathrm{Mg}$ ) in the biochar was reported in our previous work [26,27].

\subsubsection{SEM-EDS analysis}

Fig. 5 shows the SEM-EDS analysis of white ash wood and the biochar from white ash. These visual images suggested that the raw material is made of solid cells with slits, which seemed to continue inside the particle. It was clear from these images that the surface morphology of

Table 4

The effect of temperature on components of bio-oil from switch grass pyrolysis and their relative mass contents detected by GC-MS.

\begin{tabular}{|c|c|c|c|c|c|c|c|}
\hline \multirow{2}{*}{ Peak number } & \multirow{2}{*}{ Main identified compounds } & \multirow{2}{*}{ RTA (min) } & \multirow{2}{*}{ Mol. mass } & \multirow{2}{*}{ Qualitative ion, mass-to charge ratio $(\mathrm{m} / \mathrm{z})$} & \multicolumn{3}{|c|}{ Temperature $\left({ }^{\circ} \mathrm{C}\right)$} \\
\hline & & & & & 300 & 400 & 500 \\
\hline 1 & Oxiranemethanol, acetate & 2.7 & 116 & $18,42,73$ & 12.08 & 0.72 & 10.33 \\
\hline 2 & Furfural & 3.55 & 96 & $18,43,71$ & 16.28 & 22.96 & 14.93 \\
\hline 3 & Furfuryl alcohol & 3.85 & 98 & $18,43,58$ & 11.57 & 9.20 & 9.52 \\
\hline 4 & $\mathrm{~N}$-propyl-acetamide & 4.31 & 101 & $18,28,32$ & 0.74 & & \\
\hline 5 & Butyrolactone & 4.79 & 86 & $18,44,86$ & 8.52 & 13.04 & 9.04 \\
\hline 6 & 5-Methyl-2-furaldehyde & 5.74 & 110 & $18,28,44$ & 4.90 & 5.68 & 4.31 \\
\hline 7 & Phenol & 6.07 & 94 & $18,28,44$ & 7.99 & 9.26 & 4.99 \\
\hline 8 & Corylon & 6.93 & 112 & $18,28,44$ & 4.41 & 5.90 & 4.90 \\
\hline 9 & 4-Methyl-phenol & 7.84 & 108 & $28,43,108$ & & & 4.03 \\
\hline 10 & 2-Methoxy-phenol & 8.15 & 124 & $18,44,57$ & 4.53 & 6.58 & 4.81 \\
\hline 11 & 3-Elthyl-2-hydroxy-2-cyclopenten-1-one & 8.69 & 126 & $28,38,97$ & & 1.20 & 0.88 \\
\hline 12 & 2,5-Dimethyl-phenol & 9.23 & 122 & $18,44,57$ & & & 1.62 \\
\hline 13 & 2,3-Dimethyl-phenol & 9.6 & 122 & $18,28,44$ & 1.04 & & \\
\hline 14 & 4-Methoxy-3-methyl-phenol & 9.82 & 138 & $18,28,44$ & & 0.95 & \\
\hline 15 & Metacetamol & 10.17 & 151 & $18,44,64$ & 7.29 & 1.10 & 9.40 \\
\hline 16 & Anhydro-d0mannosan & 10.64 & 162 & $28,41,97$ & 1.62 & 1.81 & 1.32 \\
\hline 17 & 4-Methoxy-1,2-benzenediol & 11.3 & 140 & $18,44,124$ & 5.13 & 7.04 & 5.84 \\
\hline 18 & 4-Methyl-1,2-benzenediol & 11.77 & 124 & $28,44,97$ & & 2.23 & 1.76 \\
\hline 19 & 3,4-Dimethoxy-phenol & 12.84 & 154 & $18,44,107$ & 4.99 & & \\
\hline 20 & 2,5-Dimethyl-1,4-benzenediol & 13.38 & 138 & $18,44,58$ & 0.44 & 0.94 & 0.59 \\
\hline 21 & 4-Hydroxy-benzeneethanol & 14.01 & 138 & $28,44,123$ & & & 0.61 \\
\hline 22 & 4-Methoxy-3-[methoxymethyl]phenol & 14.4 & 168 & $18,44,58$ & 1.76 & 2.77 & 2.48 \\
\hline 23 & D-allose & 14.94 & 180 & $29,73,98$ & 4.80 & 5.27 & 7.98 \\
\hline 24 & 1-Methyl-2-[2,3,5-trimethoxyphenyl]ethylamine & 15.66 & 225 & $18,28,44$ & 1.38 & 2.82 & \\
\hline 25 & 1-[2,4,6-Trihydroxyphenyl],2-pentanone & 19.14 & 210 & $18,44,78$ & 0.53 & 0.52 & 0.66 \\
\hline
\end{tabular}


Table 5

The effect of temperature on components of bio-oil from corn stover pyrolysis and their relative mass contents detected by GC-MS.

\begin{tabular}{|c|c|c|c|c|c|c|c|}
\hline \multirow{2}{*}{ Peak number } & \multirow{2}{*}{ Main identified compounds } & \multirow{2}{*}{ RTA (min) } & \multirow{2}{*}{ Mol. mass } & \multirow{2}{*}{ Qualitative ion, mass-to charge ratio $(\mathrm{m} / \mathrm{z})$} & \multicolumn{3}{|c|}{ Temperature $\left({ }^{\circ} \mathrm{C}\right)$} \\
\hline & & & & & 300 & 400 & 500 \\
\hline 1 & Oxiranemethanol acetate & 2.7 & 116 & $18,42,73$ & 10.74 & 7.76 & 11.04 \\
\hline 2 & Furfural & 3.55 & 96 & $18,43,71$ & 15.52 & 10.81 & 13.66 \\
\hline 3 & Furfuryl alcohol & 3.85 & 98 & $18,43,58$ & 10.27 & 7.20 & 9.12 \\
\hline 4 & $\mathrm{~N}$-propyl-acetamide & 4.31 & 101 & $18,28,32$ & & & 0.24 \\
\hline 5 & Butyrolactone & 4.79 & 86 & $18,44,86$ & 8.22 & 5.17 & 8.07 \\
\hline 6 & 5-Methyl-2-furaldehyde & 5.74 & 110 & $18,28,44$ & 4.42 & 3.16 & 4.21 \\
\hline 7 & Phenol & 6.07 & 94 & $18,28,44$ & 9.21 & 6.81 & 8.65 \\
\hline 8 & Corylon & 6.93 & 112 & $18,28,44$ & 3.64 & 3.19 & 3.85 \\
\hline 9 & 4-Methyl-phenol & 7.84 & 108 & $28,43,108$ & 6.62 & 5.49 & 0.59 \\
\hline 10 & 3-Elthyl-2-hydroxy-2-cyclopenten-1-one & 8.69 & 126 & $28,38,97$ & & 0.91 & 0.82 \\
\hline 11 & 2,5-Dimethyl-phenol & 9.23 & 122 & $18,44,57$ & 1.81 & & \\
\hline 12 & 2,3-Dimethyl-phenol & 9.6 & 122 & $18,28,44$ & & 2.40 & 2.36 \\
\hline 13 & Metacetamol & 10.17 & 151 & $18,44,64$ & 7.57 & 10.21 & 8.55 \\
\hline 14 & Anhydro-d0mannosan & 10.64 & 162 & $28,41,97$ & & 5.76 & 2.18 \\
\hline 15 & 4-Methoxy-1,2-benzenediol & 11.3 & 140 & $18,44,124$ & 5.22 & 6.85 & 7.43 \\
\hline 16 & 4-Methyl-1,2-benzenediol & 11.77 & 124 & $28,44,97$ & & & 1.86 \\
\hline 17 & 3,4-Dimethoxy-phenol & 12.84 & 154 & $18,44,107$ & 4.23 & 4.96 & 4.25 \\
\hline 18 & 2,5-Dimethyl-1,4-benzenediol & 13.38 & 138 & $18,44,58$ & 0.97 & 1.60 & 0.94 \\
\hline 19 & 4-Methoxy-3-[methoxymethyl]phenol & 14.4 & 168 & $18,44,58$ & 1.50 & 2.15 & 1.37 \\
\hline 20 & D-allose & 14.94 & 180 & $29,73,98$ & 9.46 & 14.90 & 10.66 \\
\hline 21 & 4-Allyl-2,6-dimethoxy-phenol & 18.2 & 194 & $29,73,58$ & 0.20 & & \\
\hline 22 & 1-[2,4,6-Trihydroxyphenyl],2-pentanone & 19.14 & 210 & $18,44,78$ & 0.37 & 0.66 & 0.17 \\
\hline
\end{tabular}

white ash particles changed after pyrolysis, and became thinner and shrunken. The softening of the solid matrix was caused by the heat. The thermal decomposition and the melting of some compounds can break the chemical bonds of the original material. In Fig. 5(e), it can be seen that there were some carbon fibers at the surface of the biochar at $500^{\circ} \mathrm{C}$. The ideal biochar structure developed at high treatment temperature (HTT) can be divided into three processes: (a) increased proportion of aromatic C, a highly disordered amorphous mass, (b) growing sheets of conjugated aromatic carbon, turbostratically arranged; and (c) structure becoming graphitic in the third dimension with order. It is known that at $500^{\circ} \mathrm{C}$, the chemical bonds break, and some small molecular compounds are volatilized. These results are attributed to a high carbon content of $90.2 \%$ for white ash biochar at $500^{\circ} \mathrm{C}$. Under this condition, the chemical bonds would rebuild. That is why carbon fibers formed at the surface of the biochar at $500^{\circ}{ }^{\circ} \mathrm{C}$. There are some alkali metal oxides in the biomass which were difficult to volatilize, thus leading them to be enriched in the biochar. The EDS method provides a rapid qualitative, or with adequate standards, semi-quantitative analysis of elemental composition with a sampling depth of 1-2 $\mu \mathrm{m}$ [31]. In this experiment, the alkali metals of $\mathrm{Na}, \mathrm{K}, \mathrm{Ca}$ and $\mathrm{Mg}$ were tested. In Fig. 5(a, b, $c$ and d), it can be seen that, the alkali metal content increased with the increase of the temperature.

\subsection{Gas analysis}

The syngas from pyrolysis of biomass is useful if the $\mathrm{CO}, \mathrm{H}_{2}$ and $\mathrm{CH}_{4}$ contents are high. The literature [27] has reported that syngas can be used as a heat source in a recycling fluidized-bed reactor. In this experiment, the syngas was collected every $50 \mathrm{~L}$ (sometimes $25 \mathrm{~L}$ ), and the fraction of $\mathrm{CO}, \mathrm{H}_{2}$ and $\mathrm{CH}_{4}$ and $\mathrm{CO}_{2}$ was measured by GC. The composition of syngas from all three biomass is shown in Fig. 6 at three temperatures. In Fig. 6(a-i) it can be seen that the main content of the syngas was $\mathrm{CH}_{4}, \mathrm{H}_{2}, \mathrm{CO}$ and $\mathrm{CO}_{2}$. The content of the combustible gases was more than $50 \%(\mathrm{v} / \mathrm{v})$. The content of $\mathrm{CO}$ and $\mathrm{CO}_{2}$ decreased with time, while the contents of $\mathrm{H}_{2}$ and $\mathrm{CH}_{4}$ increased with time. Because there was no carrier gas in this system, the content of combustible gas ranged from $50 \%$ to $70 \%$ in syngas. The syngas can easily be combusted and its combustion flame is large. In addition, the $\mathrm{CO}$ and $\mathrm{H}_{2}$ in the syngas are valuable feedstocks in the synthesis process of liquid fuel. Li et al. [31,
27] reported the $\mathrm{Cu}-\mathrm{La}_{2} \mathrm{O}_{3}-\mathrm{ZrO}_{2} / \gamma-\mathrm{Al}_{2} \mathrm{O}_{3}$ hybrid catalysts in a onestep synthesis of dimethyl ether from syngas.

\subsection{GC-MS analysis of bio-oil}

GC-MS analysis was carried out to identify the compounds in biooils from the pyrolysis of biomass. The effect of temperature on components of bio-oil from white ash, switchgrass and corn stover pyrolysis and their relative mass contents detected by GC-MS are shown in Tables 3, 4 and 5, respectively. The compounds were ordered according to their retention times. The mol content of the chemical compounds is determined by comparing the peak areas and the relative abundance in terms of area percentage. It can be seen in Tables 3-5 that 30, 25 and 22 kinds of chemical compounds were detected from white ash, switchgrass and corn stover bio-oils, respectively. It has been reported that bio-oils produced from different types of biomass samples under similar conditions have similar composition [5]. Table 3 shows that the white ash bio-oils $\left(300^{\circ} \mathrm{C}, 400^{\circ} \mathrm{C}\right.$ and $500^{\circ} \mathrm{C}$ ) had a large amount of compounds including furfural (relative mol contents were $10.15 \%, 14.97 \%$, $12.35 \%$, respectively), Butyrolactone (relative mol contents were $8.15 \%, 8.10 \%, 6.58 \%$, respectively), metacetamol (relative mol contents were $8.36 \%, 11.70 \%, 8.11 \%$, respectively) and D-allose (relative mol contents were $5.68 \%, 11.46 \%, 10.19 \%$, respectively). Table 4 shows that the switchgrass bio-oils (at $300^{\circ} \mathrm{C}, 400^{\circ} \mathrm{C}$ and $500^{\circ} \mathrm{C}$ ) had large amounts of compounds including furfural (relative mol contents were $16.28 \%$, $22.96 \%, 14.93 \%$, respectively), Furfuryl alcohol (relative mol contents were $11.57 \%, 9.20 \%, 9.52 \%$, respectively) and Butyrolactone (relative mol contents were $8.52 \%, 13.04 \%, 9.04 \%$, respectively). Table 5 shows that the corn stover bio-oils (at $300^{\circ} \mathrm{C}, 400^{\circ} \mathrm{C}$ and $500^{\circ} \mathrm{C}$ ) have large amounts of compounds oxiranemethanol acetate (relative mol contents were $10.74 \%, 7.76 \%, 11.04 \%$, respectively), furfural (relative mol contents were $16.28 \%, 22.96 \%, 14.93 \%$, respectively), Furfuryl alcohol (relative mol contents were $11.57 \%, 9.20 \%, 9.52 \%$, respectively) and D-allose (relative mol contents were $9.46 \%, 14.90 \%, 10.66 \%$, respectively). Thus, bio-oil is a complex mixture with a lot of a chemical compounds. Furfural, D-allose and phenolic compounds are the main chemical compounds in the bio-oil for the three kinds of biomass. Similar results were reported in our previous research [23,32] and the work of Mahinpey [5]. Properties and chemical composition of bio-oil are 
distinct from petroleum fuel because of its relatively high content of water and solids, acidity and instability when heated [26]. These disadvantages limit the use of bio-oil. In the slow pyrolysis process, the water content of the bio-oil is high. The bio-oil is a good feedstock for steam reforming for hydrogen production [33].

\section{Conclusion}

The characteristics of biochar, syngas and bio-oil created from the pyrolysis of white ash, switchgrass and corn stover at the temperatures of 300,400 and $500^{\circ} \mathrm{C}$ were investigated. The biochar yields ranged from $27 \%$ to $42 \%$ and more than $52 \%$ of the carbon was captured in biochar. The ash content, $\mathrm{pH}$ value and heating value of biochar increased with the increase of the pyrolysis temperature. The biochar from pyrolysis of switchgrass had the highest $\mathrm{pH}$ value ( 8.6 at the reaction temperature of $500^{\circ} \mathrm{C}$ ). The biochar from pyrolysis of white ash had the highest heating value $\left(33.5 \mathrm{MJ} \mathrm{kg}^{-1}\right.$ at the reaction temperature of $500^{\circ} \mathrm{C}$ ). Various bands of stretches - NH-, aliphatic stretches $\mathrm{CH}$, stretches conjugate $-\mathrm{C}=\mathrm{C}-,-\mathrm{CH}_{3}$ and stretches $-\mathrm{C}-\mathrm{O}$ - were detected in the biochar. The carbon fibers formed at the temperature of $500^{\circ} \mathrm{C}$ showed that the structure of the biochar became graphitic in the third dimension at higher temperatures. The switchgrass feedstock can produce more combustible gases than those of white ash and corn stover. The content of the combustible gases $\left(\mathrm{CH}_{4}, \mathrm{H}_{2}\right.$ and $\left.\mathrm{CO}\right)$ ranged from $50 \%$ to $70 \%$ in the syngas. Furfural, D-allose and phenolic compounds are the main chemical compounds in the bio-oil for the three kinds of biomass. The biochar, syngas and bio-oil are better heat carriers than the raw biomass feedstock. Application of the three heat carriers is recommended for further study.

\section{Acknowledgments}

Financial support from the Tang Scholars Program of Cornell University, the National High Technology Research and Development Program of China (grant no. 2012AA101808) and the National Natural Science Foundation of China (project no. 51406220) are acknowledged. In addition, the authors thank the laboratories of Largus Angenent, Betta Fisher, and Johannes Lehmann at Cornell University, USA for their contributions.

\section{References}

[1] J.W. Lee, B. Hawkins, D.M. Day, D.C. Reicosky, Sustainability: the capacity of smokeless biomass pyrolysis for energy production, global carbon capture and sequestration, Energy Environ. Sci. 3 (2010) 1695-1705.

[2] F. Galembeck, Synergy in food, fuels and materials production from biomass, Energy Environ. Sci. 3 (2010) 393-399.

[3] E. Gordillo, A. Belghit, A bubbling fluidized bed solar reactor model of biomass char high temperature steam-only gasification, Fuel Process. Technol. 92 (2011) 314-321.

[4] J.J. Manyà, Pyrolysis for biochar purposes: a review to establish current knowledge gaps and research needs, Environ. Sci. Technol. 46 (2012) 7939-7954.

[5] N. Mahinpey, P. Murugan, T. Mani, R. Raina, Analysis of bio-oil, biogas, and biochar from pressurized pyrolysis of wheat straw using a tubular reactor, Energy Fuels 23 (2009) 2736-2742.

[6] D. Chiaramonti, M. Bonini, E. Fratini, G. Tondi, K. Gartner, A. Bridgwater, H. Grimm, I. Soldaini, A. Webster, P. Baglioni, Development of emulsions from biomass pyrolysis liquid and diesel and their use in engines-part 1: emulsion production, Biomass Bioenergy 25 (2003) 85-99.

[7] D. Chiaramonti, M. Bonini, E. Fratini, G. Tondi, K. Gartner, A. Bridgwater, H. Grimm, I. Soldaini, A. Webster, P. Baglioni, Development of emulsions from biomass pyrolysis liquid and diesel and their use in engines-part 2: tests in diesel engines, Biomass Bioenergy 25 (2003) 101-111.

[8] A. Bridgwater, Principles and practice of biomass fast pyrolysis processes for liquids J. Anal. Appl. Pyrolysis 51 (1999) 3-22.

[9] A. Enders, K. Hanley, T. Whitman, S. Joseph, J. Lehmann, Characterization of biochars to evaluate recalcitrance and agronomic performance, Bioresour. Technol. 114 (2012) 644-653.

[10] D. Laird, P. Fleming, B. Wang, R. Horton, D. Karlen, Biochar impact on nutrient leaching from a Midwestern agricultural soil, Geoderma 158 (2010) 436-442.

[11] L. Van Zwieten, S. Kimber, S. Morris, K. Chan, A. Downie, J. Rust, S. Joseph, A. Cowie Effects of biochar from slow pyrolysis of papermill waste on agronomic performance and soil fertility, Plant Soil 327 (2010) 235-246.

[12] D. Wang, W.Zhang, X. Hao, D. Zhou, Transport of biochar particles in saturated granular media: effects of pyrolysis temperature and particle size, Environ. Sci. Technol. 47 (2013) 821-828.

[13] J. Lehmann, M.C. Rillig, J. Thies, C.A. Masiello, W.C. Hockaday, D. Crowley, Biochar effects on soil biota-a review, Soil Biol. Biochem. 43 (2011) 1812-1836.

[14] A. Demirbas, Effects of temperature and particle size on bio-char yield from pyrolysis of agricultural residues, J. Anal. Appl. Pyrolysis 72 (2004) 243-248.

[15] J. Lehmann, J. Gaunt, M. Rondon, Bio-char sequestration in terrestrial ecosystems-a review, Mitig. Adapt. Strateg. Glob. Chang. 11 (2006) 395-419.

[16] B.P. Singh, A.L. Cowie, R.J. Smernik, Biochar carbon stability in a clayey soil as a function of feedstock and pyrolysis temperature, Environ. Sci. Technol. 46 (2012) $11770-11778$.

[17] S.M. Abit, C.H. Bolster, P. Cai, S.L. Walker, Influence of feedstock and pyrolysis temperature of biochar amendments on transport of Escherichia coli in saturated and unsaturated soil, Environ. Sci. Technol. 46 (2012) 8097-8105.

[18] M. Sánchez, E. Lindao, D. Margaleff, O. Martínez, A. Morán, Pyrolysis of agricultural residues from rape and sunflowers: production and characterization of bio-fuels and biochar soil management, J. Anal. Appl. Pyrolysis 85 (2009) 142-144.

[19] H. Abdullah, K.A. Mediaswanti, H. Wu, Biochar as a fuel: 2. Significant differences in fuel quality and ash properties of biochars from various biomass components of Mallee trees, Energy Fuels 24 (2010) 1972-1979.

[20] K. Yip, M. Xu, C.-Z. Li, S.P. Jiang, H. Wu, Biochar as a fuel: 3. Mechanistic understanding on biochar thermal annealing at mild temperatures and its effect on biochar reactivity, Energy Fuels 25 (2010) 406-414.

[21] B.B. Uzun, E. Apaydin-Varol, F. Ateş, N. Özbay, A.E. Pütün, Synthetic fuel production from tea waste: characterisation of bio-oil and bio-char, Fuel 89 (2010) 176-184.

[22] X. Cao, W. Harris, Properties of dairy-manure-derived biochar pertinent to its potential use in remediation, Bioresour. Technol. 101 (2010) 5222-5228.

[23] S.-J. Kim, S.-H. Jung, J.-S. Kim, Fast pyrolysis of palm kernel shells: influence of operation parameters on the bio-oil yield and the yield of phenol and phenolic compounds, Bioresour. Technol. 101 (2010) 9294-9300.

[24] T.J. Chen, J.L. Wu, J.Z. Zhang, J.H. Wu, L. Sun, Gasification kinetic analysis of the three pseudocomponents of biomass-cellulose, semicellulose and lignin, Bioresour. Technol. 153 (2014) 223-229.

[25] T. Chen, J. Wu, Z. Zhang, M. Zhu, L. Sun, J. Wu, D. Zhang, Key thermal events during pyrolysis and $\mathrm{CO}_{2}$-gasification of selected combustible solid wastes in a thermogravimetric analyser, Fuel 137 (2014) 77-84.

[26] T.J. Chen, C. Wu, R.H. Liu, W.T. Fei, S.Y. Liu, Effect of hot vapor filtration on the characterization of bio-oil from rice husks with fast pyrolysis in a fluidized-bed reactor, Bioresour. Technol. 102 (2011) 6178-6185.

[27] T. Chen, C. Deng, R. Liu, Effect of selective condensation on the characterization of bio-oil from pine sawdust fast pyrolysis using a fluidized-bed reactor, Energy Fuels 24 (2010) 6616-6623.

[28] J.W. Lee, M. Kidder, B.R. Evans, S. Paik, A.C. Buchanan Iii, C.T. Garten, R.C. Brown, Characterization of biochars produced from cornstovers for soil amendment, Environ. Sci. Technol. 44 (2010) 7970-7974.

[29] S. Yani, D. Zhang, An experimental study into pyrite transformation during pyrolysis of Australian lignite samples, Fuel 89 (2010) 1700-1708.

[30] Y. Huang, X. Yin, C. Wu, C. Wang, J. Xie, Z. Zhou, L. Ma, H. Li, Effects of metal catalysts on $\mathrm{CO}_{2}$ gasification reactivity of biomass char, Biotechnol. Adv. 27 (2009) 568-572.

[31] W.-T. Tsai, S.-C. Liu, H.-R. Chen, Y.-M. Chang, Y.-L. Tsai, Textural and chemical properties of swine-manure-derived biochar pertinent to its potential use as a soil amendment, Chemosphere 89 (2012) 198-203.

[32] W. Tsai, M. Lee, Y. Chang, Fast pyrolysis of rice husk: product yields and compositions, Bioresour. Technol. 98 (2007) 22-28.

[33] T. Chen, C. Wu, R. Liu, Steam reforming of bio-oil from rice husks fast pyrolysis for hydrogen production, Bioresour. Technol. 102 (2011) 9236-9240. 